\title{
Effects of Different Application Methods of Controlled-release Fertilizers on Capillary Wick Culture of Tomato
}

\author{
Takafumi Kinoshita ${ }^{1}$ \\ Western Region Agricultural Research Center (WARC), National Agriculture \\ and Food Research Organization (NARO), Sen-yucho 1-3-1, Zentsuji, Kagawa, \\ 765-8508, Japan
}

\section{Masaharu Masuda \\ Okayama University Graduate School of Natural Science and Technology, Tsushima-naka 1-1-1, Kita-ku, Okayama, 700-8530, Japan}

Additional index words. blossom-end rot, capillary watering, nitrification, xylem exudates, Solanum lycopersicum, subirrigation

\begin{abstract}
Application of controlled-release fertilizer (CRF) to root-proof capillary-wick irrigation systems (a type of subirrigation method) has both economic and environmental benefits because it does not require any equipment for fertigation and minimizes water leaching. In this study, we compared three CRF fertilization methods: 1) mixed with the substrate completely ["mixed-fertilization" (MF)]; 2) packed in bags and placed on the wick ["packed bag-fertilization" (PF)]; and 3) supplied in the water reserve tank ["tankfertilization" (TF)] in tomato cultivation using the root-proof capillary-wick irrigation system. We also refined the TF method to simplify and reduce labor requirements for fertilization of CRF and reuse of substrate. Fruit yield was lower in PF and TF than in MF because of high incidence of blossom-end rot (BER) in PF and TF during both cultivation periods, spring - summer and fall-winter. However, promotion of nitrification in TF by supplying nitrogen through the addition of bark compost and aeration of the water reserve tank increased fruit yield to the same level as that observed in MF as a result of a decrease in BER incidence. Nutrient residue in the substrate was lower in TF than in MF. On the basis of the analysis of nitrogen concentration in xylem exudates, the uptake ratio of $\mathrm{NH}_{4}-\mathrm{N} / \mathrm{NO}_{3}-\mathrm{N}$ was thought to be lower in $\mathrm{MF}$ than in $\mathrm{PF}$ and TF. The high $\mathrm{NH}_{4}-\mathrm{N}$ uptake in $\mathrm{PF}$ and TF could be the cause of calcium (Ca) deficiency and increased incidence of BER. Thus, the use of "tank fertilization" of CRF in the root-proof capillarywick irrigation system for tomato production is possible by promoting nitrification in the water reserve tank.
\end{abstract}

The efficiency of nutrient and water use is generally higher with subirrigation than with drip irrigation because subirrigation greatly reduces water leaching (Goodwin et al., 2003; Incrocci et al., 2006; Santamaria et al., 2003). For uniform water distribution in potted ornamental plants, capillary wick irrigation, a subirrigation method, has become popular in Japan since the 1980s. Capillary-wick irrigation eliminates the need for irrigation equipment (e.g., pumps, timers, sensors) because it uses capillary forces to supply the water, and this method is also labor-efficient and economical. However, in the case of long-term cultivation, the use of capillary-wick irrigation

Received for publication 28 June 2012. Accepted for publication 27 Aug. 2012.

We thank the technical support staff of the Western Region Agricultural Research Center for helping with the measurements and crop management in this study.

${ }^{1}$ To whom reprint requests should be addressed; e-mail takino@affrc.go.jp. results in weaker growth because the roots penetrate the wick and decrease capillary action. To solve this problem, Masuda (2008) developed a root-proof capillary-wick irrigation system for long-term vegetable production by making the wick impenetrable to the roots. In this irrigation system, water is stably supplied by capillary action from the side of the substrate without root invasion into the wick. Many studies have attempted to determine a suitable nutrient concentration to improve tomato cultivation by using this system (Masuda and Fukumoto, 2008; Morishige et al., 2009).

Compared with liquid fertilizer (LF), CRF is economical, because it does not require equipment to adjust the nutrient concentration and deliver the fertilizer. In our previous study, we demonstrated that CRF application was able to maintain the same fruit production with high nutrient use efficiency by suppressing luxury nutrient uptake compared with LF application (Kinoshita and Masuda, 2011a). In our study, CRF was supplied by mixing fertilizer with substrate in the usual way. However, this method of fertilization is labor-intensive, and uniform fertilization is difficult for large-scale cultivation. Moreover, reuse of substrates is difficult because residual fertilizer can remain in the substrates after the first cultivation, and this must be considered when deciding the fertilizer application rate for the subsequent cultivation.

Imano et al. (2011) investigated the "packed bag-fertilization" method of CRF for tomato cultivation. In this method, fertilizers required for each plant are packed in polyester bags and put in the substrates. Imano et al. reported that this method facilitated the removal of residual fertilizer before the substrates were reused and prevented nutrient enrichment of the substrates. Therefore, substrates fertilized using this method may have high reusability. However, this method is likely to require high costs and labor to prepare fertilizer bags for each plant, making it very difficult to introduce this method for largescale tomato cultivation.

We developed a method for applying all fertilizers required for the whole cultivation period to a water reserve tank ("tankfertilization" method). This method also facilitates the removal of residual fertilizer before reuse of the substrates and simplifies fertilizer application. Furthermore, it is expected that there is no nutrient enrichment in the substrates at the end of the cultivation period when using this method.

However, high incidence of BER was observed in tomato plants when the "tankfertilization" method was used in our preliminary investigations (unpublished data). In general, the ratio of $\mathrm{NH}_{4}-\mathrm{N}$ to total nitrogen in CRF is higher than that in commercial LF, which is usually used in soilless culture. Application of $\mathrm{NH}_{4}-\mathrm{N}$ fertilizers, or higher $\mathrm{NH}_{4}-\mathrm{N} / \mathrm{NO}_{3}-\mathrm{N}$ ratios in the nutrient solution, is often associated with increased incidence and severity of BER (Akl et al., 2003; DeKock et al., 1979, 1982; Pill and Lambeth, 1980; Pill et al., 1978). Therefore, high incidence of BER in our preliminary investigations might have been caused by high $\mathrm{NH}_{4}-\mathrm{N}$ ratios in the CRF. However, very low incidence of BER was observed when the CRF was supplied by mixing the fertilizer with substrates (Kinoshita and Masuda, 2011a). Thus, the effect of high $\mathrm{NH}_{4}-\mathrm{N}$ content in CRF on the incidence of BER is likely attributable to the different between the different methods of CRF application.

In the present study, we compared a number of CRF fertilization methods for tomato cultivation by using the root-proof capillarywick irrigation system and continued to develop the "tank-fertilization" method to decrease BER occurrence.

\section{Materials and Methods}

Three experiments were conducted at the Western Region Agricultural Research Center, Zentsuji, Kagawa, Japan (lat. $34^{\circ} 13^{\prime} \mathrm{N}$, long. $133^{\circ} 46^{\prime} \mathrm{E}$ )

Expt. 1: Development of a nitrification method in a water reserve tank. This experiment 
was conducted to develop a method for nitrification of nitrogen $(\mathrm{N})$ fertilizer in a water reserve tank to decrease the incidence of BER when using the "tank-fertilization" method. We dissolved $\left(\mathrm{NH}_{4}\right)_{2} \mathrm{SO}_{4}$ in plastic buckets (4 L) filled with well water (3 L). N concentration in the water was adjusted to $400 \mathrm{mg}$ $\mathrm{N} / \mathrm{L}$. The surface of the buckets was covered with silver mulch to prevent evaporation. Four treatments were set up: 1) addition of bark compost (15 g) to the buckets to provide the source and nest for nitrifying bacteria and aeration of the water by using an air pump (24 h) to supply oxygen; 2) addition of bark compost ( $15 \mathrm{~g})$ without aeration; 3 ) no addition of bark to the buckets and aeration of the water; and 4) no addition of bark to the buckets and no aeration of the water. Three replicate buckets were set up for each of the four treatments, and the experiment followed a completely randomized design. We collected $1 \mathrm{~mL}$ of water from each bucket every several days to control the rate of nitrification. The samples were diluted 10 times with distilled water and filtered with a membrane filter $(0.45 \mu \mathrm{m}$, pore size). Concentration of $\mathrm{NO}_{2}-\mathrm{N}$ and $\mathrm{NO}_{3}-\mathrm{N}$ was determined using ion chromatography (DX-AQ; Nippon Dionex K.K., Osaka, Japan) The operating parameters were as follows: analytical column AS12A (4 mm) with guard column AG12A (4 mm); as eluent, a solution with $2.7 \mathrm{~mm} \mathrm{Na}_{2} \mathrm{CO}_{3}$ and 0.3 $\mathrm{mm} \mathrm{NaHCO}_{3} ; 1.2 \mathrm{~mL} \cdot \mathrm{min}^{-1}$ eluent flow rate; and injection volume, $0.1 \mathrm{~mL}$. The quantification was obtained by conductivity measurements. The experiment was conducted at a fixed temperature $\left(25^{\circ} \mathrm{C}\right)$ to minimize the effects of temperature.

Expt. 2: Development of a "tank-fertilization" method. This experiment was conducted to compare three CRF fertilization methods, including the "tank-fertilization" method, for tomato cultivation by using the root-proof capillary-wick irrigation system and to investigate the effects of nitrification in the water reserve tank of the "tank-fertilization" method. The experiment was conducted twice, during spring-summer and fall-winter, seasons to investigate the seasonal difference of treatments in a plastic greenhouse (area, $108 \mathrm{~m}^{2}$ ). Seeds of large-fruit tomato plants 'House Momotaro' (Takii Seed Co., Kyoto, Japan) were sown in 128-well plug trays filled with commercial growth medium (Metro-Mix 350; Sun Gro Horticulture Distribution Inc., British Columbia, Canada) on 22 Feb. 2010 (spring-summer) and 12 Sept. 2010 (fall-winter). Seedlings were transferred to $9-\mathrm{cm}$ polyethylene pots filled with a mixed substrate [paddy soil:bark compost:perlite:peatmoss, 2:4:1:1 (v/v)] on 8 Apr. 2010 (spring-summer) and 29 Sept. 2010 (fall-winter). This substrate is reported to be suitable for the root-proof capillarywick irrigation system because of good water retention property (Kinoshita and Masuda, 2011b). On 27 Apr. 2010 (spring-summer) and 20 Oct. 2010 (fall-winter), the seedlings were transplanted at a density of 2.8 plants $/ \mathrm{m}^{2}$ into the root-proof wick irrigation system, as reported by Kinoshita and Masuda (2011a), containing the same substrate (3 L per plant). The plants were arranged in rows from south to north, and the distance between the plants and the rows was $20 \mathrm{~cm}$ and $180 \mathrm{~cm}$, respectively. Each plant was allocated one wick (length, $45 \mathrm{~cm}$; width, $4 \mathrm{~cm}$ ). The substrate surface was covered with rice husks to prevent evaporation. As the plants grew, all lateral shoots were removed and the remaining single stem was trained vertically on a string attached to a horizontal wire at a height of $2.2 \mathrm{~m}$. The flowering trusses were treated with $15 \mathrm{ppm}$ of $p$-chlorophenoxyacetic acid to promote fruit set. Trusses were thinned to contain no more than five fruits. On 15 June 2010 (spring-summer) and 15 Jan. 2011 (fall-winter), the plants were topped with two leaves retained above the fifth truss. Fruit harvesting continued until 4 Aug. 2010 (springsummer) and 5 Apr. 2011 (fall-winter). The greenhouse was heated at night to maintain a minimum temperature of $13{ }^{\circ} \mathrm{C}$, and ventilation was initiated during the daytime when temperature was higher than $28^{\circ} \mathrm{C}$.

CRF was supplied using the following four methods (Fig. 1): 1) mixed with the substrate completely (MF); 2) packed in bags and placed on the wick (PF); 3) supplied in the water reserve tank (TF); and 4) supplied in the water reserve tank and nitrified by adding bark compost and aeration, as a result of Expt. 1 ["tank-fertilization + nitrification" (TFN)]. The nutrient components of CRF are shown in Table 1 . The ratio of $\mathrm{NO}_{3}-\mathrm{N}: \mathrm{NH}_{4}-\mathrm{N}$ was $\approx 2: 1$. Ash of chicken droppings was mixed with the substrate in all treatments to adjust $\mathrm{pH}$ and to supply macro- and microminerals, except N. All fertilizers were supplied before planting. In PF, all CRFs except ash of chicken droppings were packed in polyester bags with water permeability $(9.5 \mathrm{~cm}$ long $\times 7.0 \mathrm{~cm}$ wide, spring-summer; $10.5 \mathrm{~cm}$ long $\times 11.0 \mathrm{~cm}$ wide, fall-winter) and placed on each wick. In TF and TFN, all CRFs supplied for all plants, except ash of chicken droppings, were packed with polyester sheet that divided each fertilizer type applied in the water reserve tank (20 L). In TF and TFN, one water reserve tank was used for irrigating plants of all replicates. In addition, a treatment supplying LF was set. For LF, a half-strength commercial nutrient solution with an electrical conductivity of $\approx 1.4 \mathrm{dS} \cdot \mathrm{m}^{-1}$ (Otsuka Chemical Co. Ltd., Osaka, Japan) and containing $\mathrm{N}\left(\mathrm{NO}_{3}-\mathrm{N}: \mathrm{NH}_{4}-\mathrm{N}=9: 1\right)$, phosphorus $(\mathrm{P})$, potassium $(\mathrm{K}), \mathrm{Ca}$, and magnesium $(\mathrm{Mg})$ at concentrations of 130 , $26,168,82$, and $18 \mathrm{mg} \cdot \mathrm{L}^{-1}$, respectively, was applied to the plants. The experimental design was a randomized complete block with three replicate plots of each treatment. Each plot was comprised of six plants, all of which were in a single container.

$\mathrm{NH}_{4}-\mathrm{N}$ and $\mathrm{NO}_{3}-\mathrm{N}$ concentrations in the nutrient solution in the water reserve tanks were determined using a reflectometer (RQ flex; Merck KGaA, Darmstadt, Germany) three times a week. Individual mature fruits from six plants per plot were harvested from each plot once or twice a week, and the fresh weight of each fruit was measured. Marketable fruit was defined as fruit weighing over $80 \mathrm{~g}$ with no physiological damage. Fruit Brix was measured using a digital refractometer (PAL-1; ATAGO Co., Ltd., Tokyo, Japan).

The petiole of the leaflet just under each fruit truss was collected $\approx 2$ weeks after
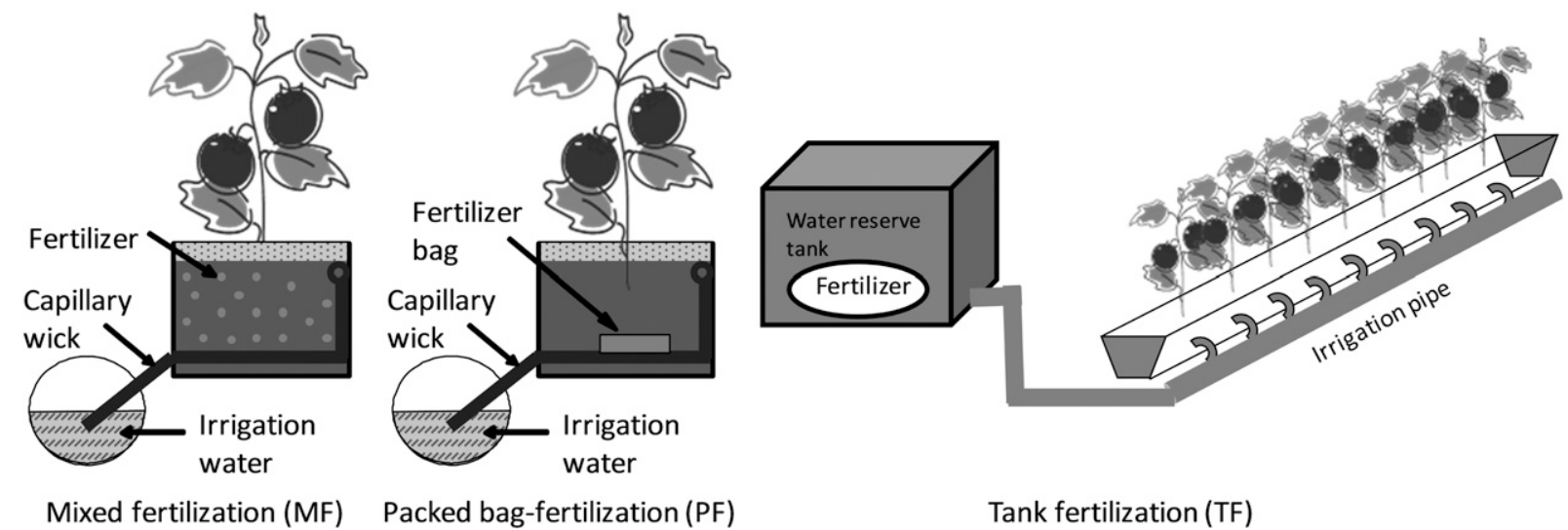

Fig. 1. Diagram of the differences in fertilization methods used in Expts. 2 and 3. 
Table 1. Fertilizer component concentrations in the substrate of controlled-release fertilizer application treatments (g/plant, Expt. 2).

\begin{tabular}{lrccccc}
\hline Japanese standard name of fertilizer & Days $^{\mathrm{z}}$ & Nitrogen & Phosphorus & Potassium & Calcium & Magnesium \\
\hline Spring-summer crop & & & & & & \\
$\quad$ Ash of chicken droppings & & & 0.9 & 1.5 & 1.6 & 0.4 \\
$\quad$ Eco long total 313 & 70 & 1.4 & 0.5 & 1.1 & & 0.1 \\
$\quad$ Super eco long & $\mathrm{x} 100$ & 2.9 & 1.1 & 2.4 & & \\
$\quad$ Long calcium nitrate & 100 & 1.6 & & & 2.1 & \\
$\quad$ Coating potassium & 100 & 0.2 & & 2.7 & & 0.3 \\
$\quad$ Long magnesium sulfate & 100 & & & & & 0.8 \\
$\quad$ Total & & 6.0 & 2.5 & 7.7 & 3.8 & \\
& & & & & & \\
Fall-winter crop & & & 0.9 & 1.5 & 1.6 & 0.4 \\
$\quad$ Ash of chicken droppings & 100 & 3.9 & 1.4 & 3.2 & & 0.4 \\
$\quad$ Eco long total 313 & $\mathrm{y} 100$ & 1.4 & 0.5 & 1.2 & & \\
$\quad$ Super eco long & 100 & 2.5 & & & 3.4 & \\
$\quad$ Long calcium nitrate & 100 & 0.3 & & 4.4 & & 0.4 \\
$\quad$ Coating potassium & 100 & & & & & \\
$\quad$ Long magnesium sulfate & & 8.0 & 2.8 & 10.3 & 5.0 & 1.1 \\
$\quad$ Total & &
\end{tabular}

${ }^{\mathrm{z}}$ Number of days until $80 \%$ of the amount is released at $25{ }^{\circ} \mathrm{C}$.

${ }^{\mathrm{y}}$ This fertilizer contained nitrogen, phosphorus, potassium, and magnesium in the ratio 13:4.8:10.8:1.2 plus small amounts of micronutrients.

${ }^{\mathrm{x}}$ Nutrients are released sigmoidally in contrast to linear nutrient release in other fertilizers.

anthesis as described by Tanaka (2003). Samples were immediately homogenized by adding distilled water at a 1:9 ratio of sample $(\mathrm{g})$ to water $(\mathrm{mL})$. The mixture was centrifuged for $5 \mathrm{~min}$ at $6000 \mathrm{rpm}$ and the supernatant was diluted 10 times with distilled water and filtered with a membrane filter $(0.45 \mu \mathrm{m}$, pore size $)$. Concentration of $\mathrm{NH}_{4}-\mathrm{N}$ and $\mathrm{Ca}$ in the filtrate (petiole juice) was determined using ion chromatography (detailed in Expt. 1). The operating parameters were as follows: analytical column CS12A (4 mm) with guard column CG12A (4 mm); as eluent, a solution with $20 \mathrm{~mm}$ methanesulfonic acid; $1.0 \mathrm{~mL} \cdot \mathrm{min}^{-1}$ eluent flow rate; and injection volume, $0.1 \mathrm{~mL}$. The quantification was obtained by conductivity measurements.

The substrates before and after cultivation from each plot were air-dried. Total $\mathrm{N}$ content of the dried substrates $(600 \mathrm{mg}$ per plot) was measured using an $\mathrm{NC}$ analyzer (Vario MAX CN; Elementar Analysensysteme, Germany). Phosphorus concentration was measured using Truog's method (Truog, 1930). In addition, dried substrates ( $5 \mathrm{~g}$ per plot) were extracted with $100 \mathrm{~mL}$ of $2 \mathrm{M}\left(\mathrm{NH}_{4}\right)_{2} \mathrm{SO}_{4}$ using a shaker $(60 \mathrm{~min})$. The mixture was filtered through No. 6 filter paper and diluted 10 times with distilled water and $\mathrm{K}, \mathrm{Ca}$, and $\mathrm{Mg}$ concentrations were measured using emission spectroscopy (ICP-AES) (SPS-1500NR; Seiko Instrument Inc., Chiba, Japan).

Remaining CRFs of PF, TF, and TFN after cultivation were dried in an open-air oven at $80{ }^{\circ} \mathrm{C}$ for $3 \mathrm{~d}$. Total $\mathrm{N}$ content of the dried CRFs (600 mg per plot) was measured using the NC analyzer, as mentioned previously. Dried CRFs (500 mg per plot) were digested by $\mathrm{H}_{2} \mathrm{SO}_{4}-\mathrm{H}_{2} \mathrm{O}_{2}$ and diluted to $100 \mathrm{~mL}$ with ultrapure water. After the samples were diluted 10 to 50 times with ultrapure water, $P$ concentration was measured with the vanadomolybdophosphoric yellow color method using an absorption spectrophotometer (Synergy HT SIAFR; BioTek Instruments Inc., VT) at $440 \mathrm{~nm}$, and $\mathrm{K}, \mathrm{Ca}$, and $\mathrm{Mg}$ concentrations were measured using ICP-AES as mentioned previously.

Expt. 3: Uptake ratio of $\mathrm{NH}_{4}-\mathrm{N}_{\mathrm{N}} \mathrm{N}_{3}-\mathrm{N}$ and nitrogen conversion of supplied fertilizer. This experiment was conducted to investigate the difference in the uptake ratio of $\mathrm{NH}_{4}-\mathrm{N} / \mathrm{NO}_{3}-\mathrm{N}$ and $\mathrm{N}$ conversion of the supplied fertilizer and to explain the reason of the difference in BER rate among the different CRF application methods. The experiment was conducted in a plastic greenhouse (area, $252 \mathrm{~m}^{2}$ ). Seeds of 'House Momotaro' were sown in 128-well plug trays filled with the same growth medium as Expt. 2 on 12 Sept. 2010. Seedlings were transferred to 9-cm polyethylene pots filled with a same substrate as Expt. 2 on 29 Sept. 2010. On 28 Oct. 2010 , the seedlings were transplanted to the root-proof wick-irrigation system for home use (Tomato-Meijin; Growwell, Fukuoka, Japan). In this system, plastic boxes $(35 \mathrm{~cm}$ long $\times 24 \mathrm{~cm}$ wide $\times 27 \mathrm{~cm}$ high) containing the same substrate ( $3 \mathrm{~L}$ per plant) were used for planting two plants per box, and the substrates were separated for each plant. The plastic boxes were placed on 4-L water reserve tanks $(43 \mathrm{~cm}$ long $\times 41 \mathrm{~cm}$ wide $\times$ $4 \mathrm{~cm}$ high). Each plant was allocated one wick ( $45 \mathrm{~cm}$ long $\times 4 \mathrm{~cm}$ wide). The substrate surface was covered with rice husks to prevent evaporation. $\mathrm{CRF}\left(6 \mathrm{~N}-6 \mathrm{P}_{2} \mathrm{O}_{5^{-}}\right.$ $6 \mathrm{~K}_{2} \mathrm{O}, 4 \mathrm{NO}_{3}-\mathrm{N}: 6 \mathrm{NH}_{4}-\mathrm{N}, 40$ d type; JCAM AGRI. Co., Ltd., Tokyo, Japan) was supplied (2.0 g N/plant) using the following three methods: 1) MF; 2) PF; and 3) TF. In $\mathrm{PF}$ and TF, the CRF was packed in polyester bags $(9.5 \mathrm{~cm}$ long $\times 7.0 \mathrm{~cm}$ wide $)$ for each plant and placed on the wick (PF) or supplied in the water reserve tank (TF). $\mathrm{NH}_{4}-\mathrm{N}$ in the fertilizer was labeled with ${ }^{15} \mathrm{~N}$ (6.6 atom $\left.\%{ }^{15} \mathrm{NH}_{4}-\mathrm{N}\right)$. Ash of chicken droppings was mixed with the substrate in all treatments (10 g/plant). The experimental design was a completely randomized design with three replicates per treatment. Each replicate contained two plants. The greenhouse temperature was controlled as described in Expt. 2.

Xylem exudates were collected from two plants in each plot on 8 Dec. 2010 , at the early stage of fruit enlargement of the first fruit truss. For this purpose, the plants were decapitated at $5 \mathrm{~cm}$ above the ground at $1000 \mathrm{HR}$, and xylem exudates were collected for $3 \mathrm{~h}$, as described in Kinoshita and Masuda (2011a). The samples were stored at $-20{ }^{\circ} \mathrm{C}$ until analysis. Concentrations of $\mathrm{NH}_{4}-\mathrm{N}$ and $\mathrm{NO}_{3}-\mathrm{N}$ in the exudates were determined using ion chromatography, as described in Expts. 1 and 2. Total $\mathrm{N}$ concentration in the exudates was measured using the $\mathrm{NC}$ analyzer, as described in Expt. 2. Organic $\mathrm{N}$ concentration was calculated by deducting $\mathrm{NH}_{4}-\mathrm{N}$ and $\mathrm{NO}_{3}-\mathrm{N}$ concentrations from the total $\mathrm{N}$ concentration. Furthermore, anion and cation fractions in the exudates were extracted using cation and anion exchange resins (cation, Amberlite IR120B-NA; anion, Amberlite IRA400J-CL; Organo Corp., Tokyo, Japan) by the batch method as follows: $\approx 500 \mathrm{mg}$ of each resin and $1.5 \mathrm{~mL}$ of the exudates per plot were put in a plastic tube $(2.0 \mathrm{~mL})$ and shaken $24 \mathrm{~h}$. The supernatant was concentrated by a evaporator and atom percentage of ${ }^{15} \mathrm{~N}$ for the concentrate was determined using stable isotope mass spectrometers (ANCA-GSL+ GEO20-20; Europa Scientific Ltd., Crewe, U.K.). Nitrogen formed in the supernatant exchanged with cation resins was regarded as an anion form, and that exchanged with anion resins was regarded as a cation form, because almost all $\mathrm{N}$ in the exudates probably carried an electrical charge.

Data analysis. One-way analysis of variance and Tukey's multiple comparison tests were performed using the statistical software Excel Tokei 2010 (SSRI, Tokyo, Japan).

\section{Results and Discussion}

Expt. 1: Development of a nitrification method in a water reserve tank. $\mathrm{NO}_{2}-\mathrm{N}$ and $\mathrm{NO}_{3}-\mathrm{N}$ concentrations in the water buckets are shown in Figure 2. The rate of nitrification to $\mathrm{NO}_{3}-\mathrm{N}$ was highest in Treatment 1 (addition of bark compost and aeration). In Treatment 3 (only aeration), the rate of nitrification to $\mathrm{NO}_{2}-\mathrm{N}$ was comparatively high, but there was little $\mathrm{NO}_{3}-\mathrm{N}$ production; there was very little $\mathrm{NO}_{2}-\mathrm{N}$ and $\mathrm{NO}_{3}-\mathrm{N}$ production in Treatment 2 (only bark compost addition). Therefore, the rate of nitrification to $\mathrm{NO}_{3}-\mathrm{N}$ remained low with only the addition of bark compost or aeration of the water. However, efficient nitrification to $\mathrm{NO}_{3}-\mathrm{N}$ was achieved by combining the addition of bark compost (for the nest of nitrifying bacteria) and aeration of the water, as reported by Shinohara (2006) and Shinohara et al. (2011).

Expt. 2: Development of the tank-fertilization method. Changes in the ratio of $\mathrm{NH}_{4}-\mathrm{N}$ concentration to total $\mathrm{N}\left(\mathrm{NO}_{3}-\mathrm{N}+\mathrm{NH}_{4}-\mathrm{N}\right)$ concentration in the water reserve tank in TF, TFN, and LF are shown in Figure 3. The ratio of $\mathrm{NH}_{4}-\mathrm{N}$ concentration was lower in TFN than in TF in both cropping seasons (spring-summer and fall-winter). Therefore, 

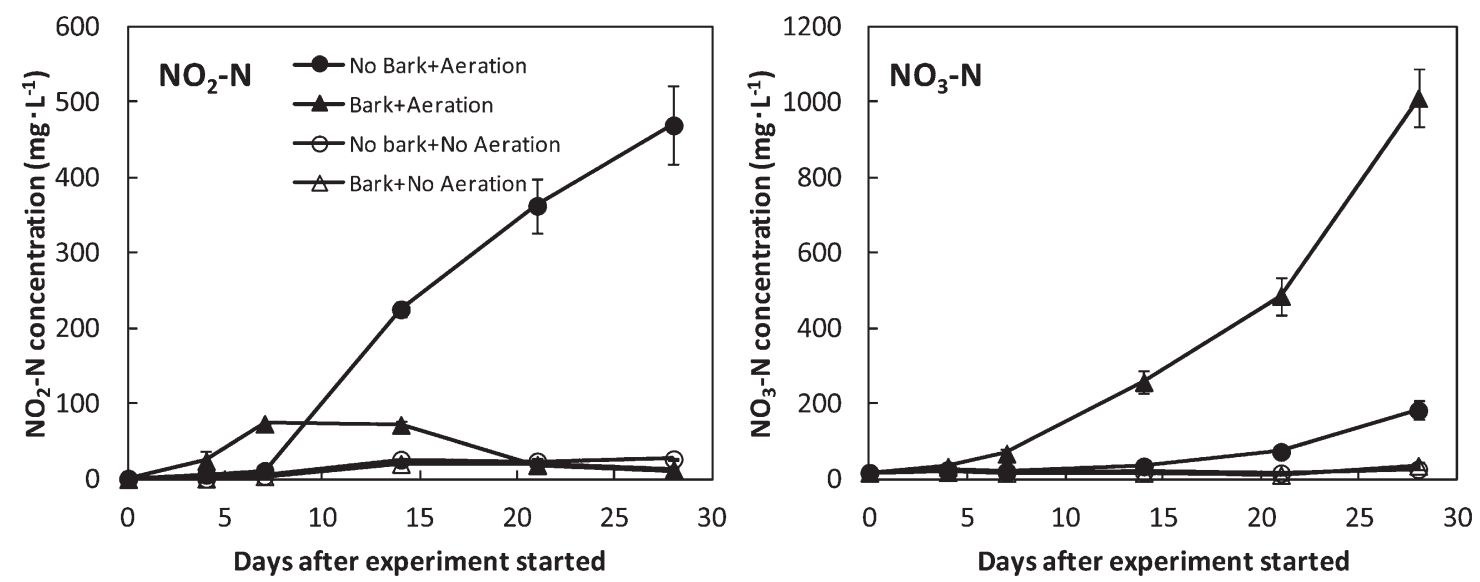

Fig. 2. $\mathrm{NO}_{2}-\mathrm{N}$ and $\mathrm{NO}_{3}-\mathrm{N}$ concentrations in the four nitrification treatment of Expt. 1. Mean $\pm \mathrm{SE}(\mathrm{n}=3)$.
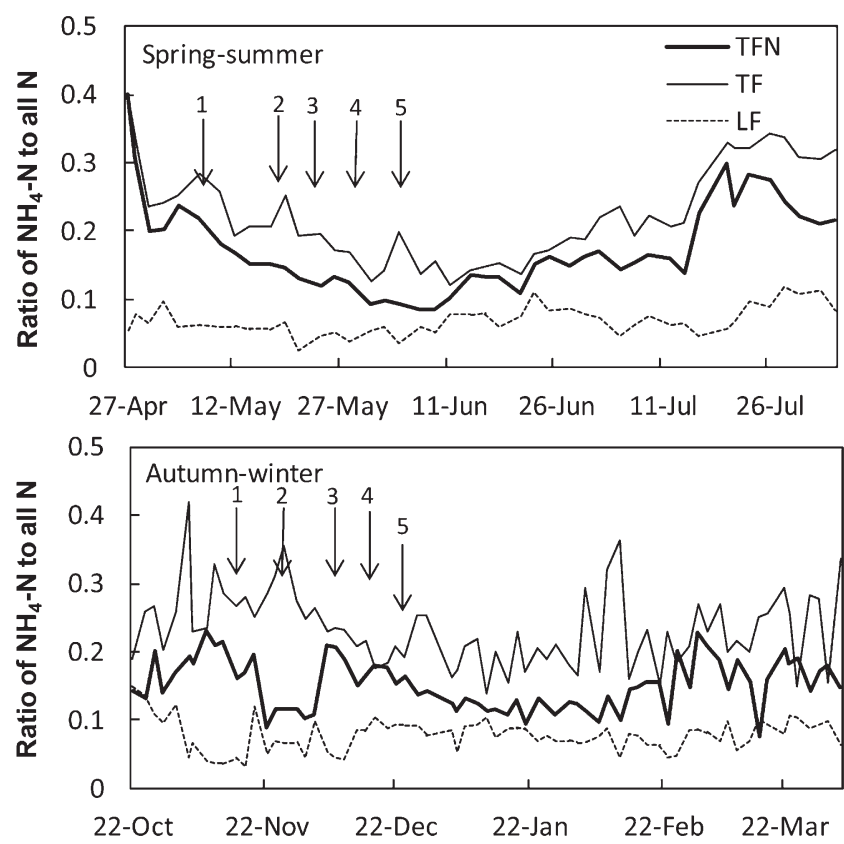

Fig. 3. Change in the ratio of $\mathrm{NH}_{4}-\mathrm{N}$ concentration to total nitrogen (N) $\left(\mathrm{NO}_{3}-\mathrm{N}+\mathrm{NH}_{4}-\mathrm{N}\right)$ concentration in the water reserve tank in the different fertilization methods (Expt. 2). The numbers and arrows indicate the flowering period of each truss.

nitrification treatment was definitely effective in reducing the ratio of $\mathrm{NH}_{4}-\mathrm{N}$ concentration in the tank. Fluctuations in the ratio of $\mathrm{NH}_{4}-\mathrm{N}$ concentration in TF and TFN were greater in fall-winter than in spring-summer. The nitrification rate was probably kept high in spring-summer because of the warmer temperatures (nitrification rate is generally high at warmer temperatures), whereas the rate is likely to have decreased on colder days in the fall-winter season. Thus, the difference in nitrification rate between cropping seasons is likely a result of difference in water temperature.

There were no significant differences among CRF treatments in the total amount of nutrient residue in the substrates and the fertilizer at the end of the experiment, except $\mathrm{P}$ and $\mathrm{K}$ in fall-winter (Table 2). Therefore, the difference in the elution rate of the fertilizer and the apparent nutrient uptake varied little among the different CRF application treatments. On the other hand, nutrient residue in the substrates in $\mathrm{TF}$ and TFN was lower than that in MF, except $\mathrm{Mg}$ in spring-summer and $\mathrm{Ca}$ in fall-winter. This indicates that TF and TFN prevent nutrient enrichment of the substrates and the substrates treated by these methods have high reusability.

Fruit yield and BER incidence are shown in Table 3. Marketable fruit yield was lower in $\mathrm{PF}$ and $\mathrm{TF}$ than in MF in both seasons. Marketable fruit yield in TFN was greater than that in TF in both seasons and equivalent to that in MF. In spring-summer, fruit yield in CRF-supplied plants was lower than that in LF-supplied plants. This may be caused by low nutrient elution in the second half of the growing season in plants supplied with CRF judging from the smaller stem diameter and fruit yield of the upper trusses (data not shown) in CRF-supplied plants. There was no significant difference in fruit weight, whereas the lower marketable fruit number differed significantly among CRF application treatments. Total fruit number was similar among treatments in the fall-winter season, but during the spring-summer season, the highest fruit number was observed in MF and the smallest in TF among the treatments of CRF application. BER incidence was generally higher in PF and TF than in the other treatments for the first two trusses in the spring-summer and the first truss in the fall-winter. Therefore, the difference in marketable fruit weight between the treatments was likely caused by the difference in BER incidence as well as the total fruit number in both seasons. BER incidence tended to be higher in the spring-summer season than in the fall-winter season. Our results are in agreement with those of Ikeda and Osawa (1988) who reported that the incidence of BER was higher in spring-summer than in fall-winter in tomato plants when the $\mathrm{NH}_{4}-\mathrm{N}$ rate in the supplied $\mathrm{N}$ was high.

Therefore, it was revealed that BER incidence differs among the CRF application treatments. It has been reported that $\mathrm{Ca}$ uptake from 1 to 3 weeks after anthesis strongly affects the occurrence of BER (Chiu and Bould, 1976; Ehret and Ho, 1986; El-Gizawy and Adams, 1986; Gerard and Hipp, 1968; Westerhout, 1962). Ca concentration in the petiole juice at the early stage of fruit growth $(\approx 2$ weeks after anthesis) of trusses with high BER incidence differed significantly between treatments (Table 4). Moreover, there was a significant correlation between the incidence of BER and $\mathrm{Ca}$ concentration (Fig. 4). Thus, the difference in $\mathrm{Ca}$ concentration at the early stage of fruit growth is likely to have led to the difference in BER incidence between the treatments. BER incidence tended to increase drastically when $\mathrm{Ca}$ concentration decreased below 100 to $200 \mathrm{mg} \cdot \mathrm{L}^{-1}$. Morikuni and Shimada (2000) also reported that BER incidence increased when $\mathrm{Ca}$ concentration in the petiole juice decreased below $200 \mathrm{mg} \cdot \mathrm{L}^{-1}$. Furthermore, He et al. (1998) suggested that $\mathrm{Ca}$ deficiency could be diagnosed by checking the $\mathrm{Ca}$ concentration in the petiole juice 
Table 2. Amount of nutrient residue in the substrates and in the fertilizer at the end of the experiment for the different fertilization methods ( $\mathrm{g} / \mathrm{plant}$, Expt. 2).

\begin{tabular}{|c|c|c|c|c|c|c|c|c|c|c|c|c|c|c|c|}
\hline \multirow[b]{2}{*}{ Treatment ${ }^{z}$} & \multicolumn{5}{|c|}{ Substrate } & \multicolumn{5}{|c|}{ Fertilizer } & \multicolumn{5}{|c|}{ Total } \\
\hline & $\mathrm{N}$ & $\mathrm{P}$ & K & $\mathrm{Ca}$ & $\mathrm{Mg}$ & $\mathrm{N}$ & $\mathrm{P}$ & K & $\mathrm{Ca}$ & $\mathrm{Mg}$ & $\mathrm{N}$ & $\mathrm{P}$ & $\mathrm{K}$ & $\mathrm{Ca}$ & $\mathrm{Mg}$ \\
\hline MF & $5.29 \mathrm{ab}^{\mathrm{y}}$ & $2.48 \mathrm{a}$ & $2.49 \mathrm{a}$ & $4.84 \mathrm{~b}$ & $0.81 \mathrm{~b}$ & - & - & - & - & - & 5.29 & $2.48 \mathrm{a}$ & 2.49 & $4.84 \mathrm{~b}$ & $0.81 \mathrm{~b}$ \\
\hline $\mathrm{PF}$ & $4.54 \mathrm{bc}$ & $1.12 \mathrm{c}$ & $1.03 \mathrm{~b}$ & $3.23 \mathrm{c}$ & $0.69 \mathrm{~b}$ & 1.13 & 1.19 & 2.03 & 1.11 & 0.27 & 5.67 & $2.32 \mathrm{a}$ & 3.06 & $4.34 \mathrm{~b}$ & $0.97 \mathrm{ab}$ \\
\hline TFN & $4.19 \mathrm{c}$ & $1.08 \mathrm{c}$ & $0.76 \mathrm{~b}$ & $3.19 \mathrm{c}$ & $0.64 \mathrm{~b}$ & 0.85 & 0.86 & 2.11 & 0.73 & 0.25 & 5.05 & $1.94 \mathrm{~b}$ & 2.87 & $3.92 \mathrm{~b}$ & $0.89 \mathrm{~b}$ \\
\hline LF & $5.77 \mathrm{a}$ & $1.69 \mathrm{~b}$ & $3.21 \mathrm{a}$ & $6.24 \mathrm{a}$ & $1.25 \mathrm{a}$ & - & - & - & - & - & 5.77 & $1.69 \mathrm{c}$ & 3.21 & $6.24 \mathrm{a}$ & $1.25 \mathrm{a}$ \\
\hline ANOVA & $* * *$ & $* * *$ & $* * *$ & $* * *$ & $* *$ & - & - & - & - & - & NS & $* * *$ & NS & $* *$ & $*$ \\
\hline MF & $5.69 \mathrm{a}^{\mathrm{y}}$ & $1.97 \mathrm{a}$ & $3.66 \mathrm{a}$ & 7.81 & $1.40 \mathrm{a}$ & - & - & - & - & - & 5.69 & $1.97 \mathrm{a}$ & $3.66 \mathrm{bc}$ & 7.81 & 1.40 \\
\hline $\mathrm{PF}$ & $4.35 \mathrm{~b}$ & $0.53 \mathrm{c}$ & $0.57 \mathrm{~b}$ & 6.07 & $1.10 \mathrm{~b}$ & 1.47 & 1.24 & 3.18 & 1.40 & 0.47 & 5.82 & $1.77 \mathrm{ab}$ & $3.75 \mathrm{ab}$ & 7.46 & 1.58 \\
\hline $\mathrm{TF}$ & $4.48 \mathrm{~b}$ & $0.61 \mathrm{c}$ & $0.52 \mathrm{~b}$ & 7.37 & $1.19 \mathrm{~b}$ & 1.33 & 1.06 & 3.96 & 1.13 & 0.35 & 5.82 & $1.67 \mathrm{ab}$ & $4.48 \mathrm{a}$ & 8.50 & 1.54 \\
\hline TFN & $4.55 \mathrm{~b}$ & $0.58 \mathrm{c}$ & $0.51 \mathrm{~b}$ & 7.00 & $1.16 \mathrm{~b}$ & 1.18 & 1.05 & 3.57 & 0.92 & 0.35 & 5.73 & $1.63 \mathrm{~b}$ & $4.08 \mathrm{a}$ & 7.93 & 1.51 \\
\hline LF & $5.46 \mathrm{a}$ & $1.19 \mathrm{~b}$ & $2.32 \mathrm{a}$ & 7.51 & $1.51 \mathrm{a}$ & - & - & - & - & - & 5.46 & $1.19 \mathrm{c}$ & $2.32 \mathrm{c}$ & 7.51 & 1.51 \\
\hline ANOVA & $* *$ & $* * *$ & *** & NS & ** & - & - & - & - & - & NS & *** & ** & NS & NS \\
\hline
\end{tabular}

${ }^{{ }^{2} \mathrm{MF}}=$ mixed-fertilization; $\mathrm{PF}=$ packed bag-fertilization; TF $=$ tank-fertilization; TFN $=$ tank-fertilization + nitrification; $\mathrm{LF}=$ liquid fertilizer.

${ }^{y}$ Different letters indicate significant differences among treatments $(P \leq 0.05)$.

Ns, $*, * *, * * *$ Nonsignificant or significant at $P \leq 0.05,0.01$, or 0.001 , respectively.

$\mathrm{N}=$ nitrogen; $\mathrm{P}=$ phosphorus; $\mathrm{K}=$ potassium; $\mathrm{Ca}=$ calcium; $\mathrm{Mg}=$ magnesium; $\mathrm{ANOVA}=$ analysis of variance.

Table 3. Fruit yield, soluble solids concentration, and BER incidence in the different fertilization methods (Expt. 2).

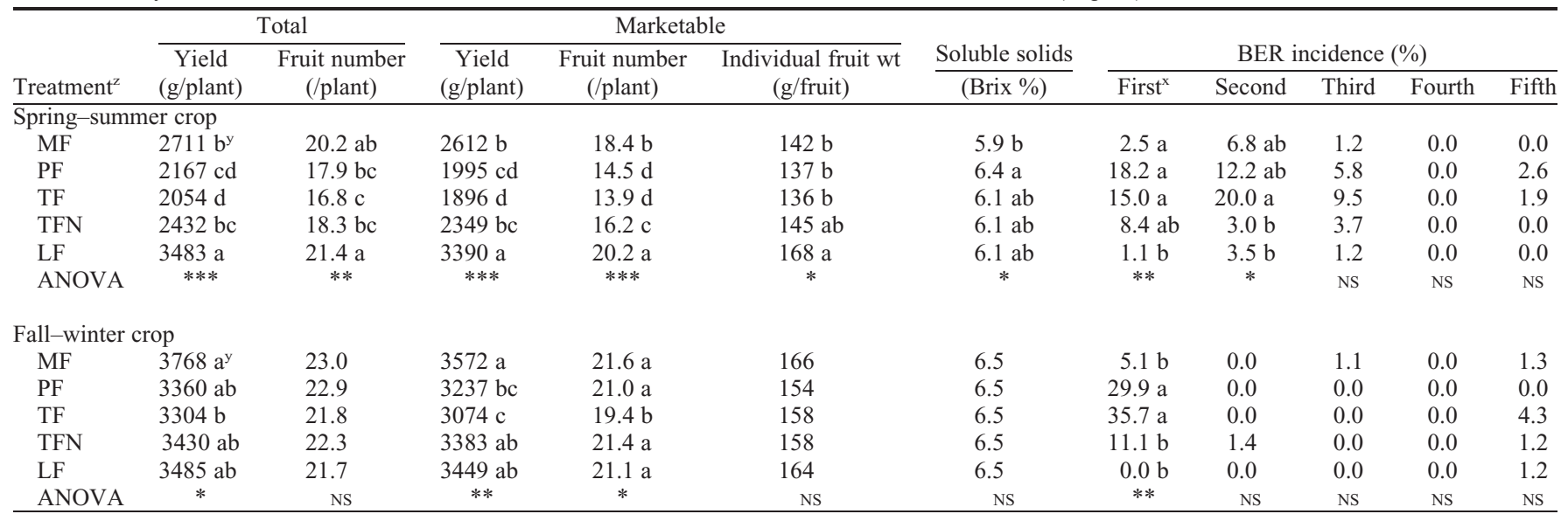

${ }^{\mathrm{z}} \mathrm{MF}=$ mixed-fertilization; $\mathrm{PF}=$ packed bag-fertilization; $\mathrm{TF}=$ tank-fertilization; TFN $=$ tank-fertilization + nitrification; $\mathrm{LF}=$ liquid fertilizer.

${ }^{y}$ Different letters indicate significant differences among treatments $(P \leq 0.05)$.

${ }^{\mathrm{x}}$ Fruit truss number.

NS, *,*****Nonsignificant or significant at $P<0.05,0.01$, or 0.001 , respectively.

$\mathrm{BER}=$ blossom-end rot; $\mathrm{ANOVA}=$ analysis of variance.

Table 4. $\mathrm{Ca}$ and $\mathrm{NH}_{4}-\mathrm{N}$ concentrations in the petiole juice at the early stage of fruit growth in the different fertilization methods (Expt. 2).

\begin{tabular}{|c|c|c|c|c|c|c|c|c|}
\hline \multirow{2}{*}{ Treatment $^{z}$} & \multicolumn{4}{|c|}{$\mathrm{Ca}\left(\mathrm{mg} \cdot \mathrm{L}^{-1}\right)$} & \multicolumn{4}{|c|}{$\mathrm{NH}_{4}-\mathrm{N}\left(\mathrm{mg} \cdot \mathrm{L}^{-1}\right)$} \\
\hline & \multicolumn{3}{|c|}{ Spring-summer crop } & 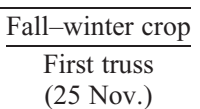 & \multicolumn{3}{|c|}{ Spring-summer crop } & $\begin{array}{c}\text { Fall-winter crop } \\
\text { First truss } \\
\text { (25 Nov.) }\end{array}$ \\
\hline $\mathrm{PF}$ & $65 \mathrm{c}$ & $236 \mathrm{~b}$ & $230 \mathrm{c}$ & $84 \mathrm{ab}$ & $448 \mathrm{a}$ & 117 & 130 & $67 \mathrm{ab}$ \\
\hline TF & $81 \mathrm{c}$ & $267 \mathrm{~b}$ & $308 \mathrm{bc}$ & $76 \mathrm{~b}$ & $396 \mathrm{ab}$ & 156 & 139 & $80 \mathrm{a}$ \\
\hline TFN & $132 b c$ & $464 \mathrm{a}$ & $507 \mathrm{ab}$ & $152 \mathrm{ab}$ & $372 a b c$ & 108 & 132 & $64 \mathrm{ab}$ \\
\hline LF & $583 \mathrm{a}$ & $626 \mathrm{a}$ & $718 \mathrm{a}$ & $190 \mathrm{a}$ & $279 \mathrm{bc}$ & 112 & 115 & $71 \mathrm{ab}$ \\
\hline
\end{tabular}

${ }^{{ }^{\mathrm{M}} \mathrm{MF}}=$ mixed-fertilization; $\mathrm{PF}=$ packed bag-fertilization; $\mathrm{TF}=$ tank-fertilization; $\mathrm{TFN}=$ tank-fertilization + nitrification; $\mathrm{LF}=$ liquid fertilizer.

${ }^{y}$ Date of collecting petioles.

${ }^{\mathrm{x}}$ Different letters indicate significant differences among treatments $(P<0.05)$.

Ns, *, **Nonsignificant or significant at $P<0.05$ or 0.01 , respectively.

$\mathrm{Ca}=$ calcium; ANOVA $=$ analysis of variance.

just under the truss at the early stage of fruit growth. Therefore, it may be possible to diagnose $\mathrm{Ca}$ deficiency, and thus the likelihood of the occurrence of BER, by checking $\mathrm{Ca}$ concentration in the petiole juice.

The high incidence of BER in PF and TF was not the result of low Ca supply from the fertilizers because there was very little difference in the rate of fertilizer elution between the treatments. It has been reported that increases in the incidence of BER are caused by environmental conditions such as soil-water stress (Gerard and Hipp, 1968; Pill and Lambeth, 1980), high temperature (Wui and Takano, 1995), and low relative humidity at night (Bradfield and Guttridge, 1984; Ho, 1989). However, these factors were not the reasons for the differences observed in the incidence of BER between the treatments in the current study because the environmental conditions were the same in each treatment. 

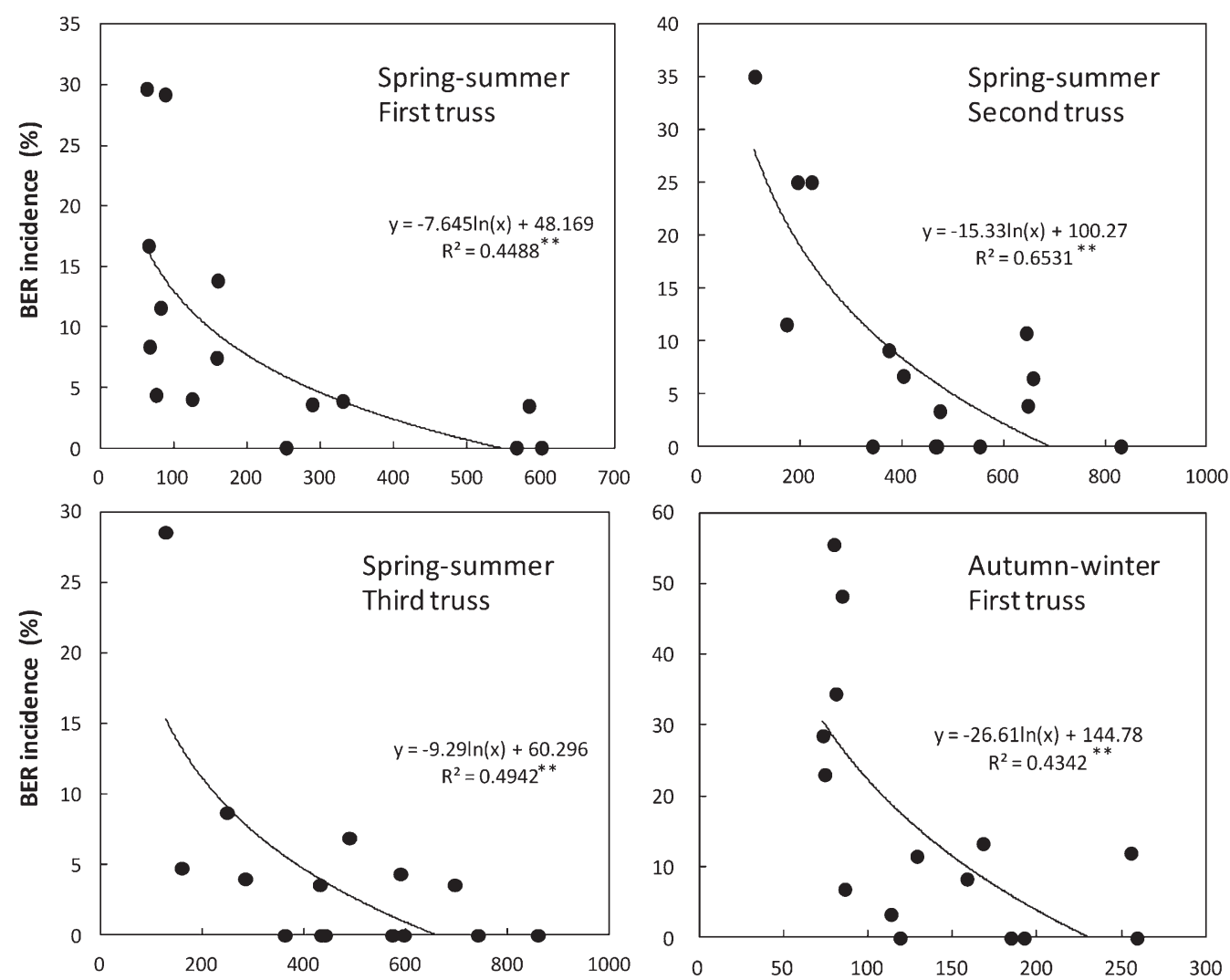

Ca concentration in the petiole juice $\left(\mathrm{mg} \cdot \mathrm{L}^{-1}\right)$

Ca concentration in the petiole juice $\left(\mathrm{mg} \cdot \mathrm{L}^{-1}\right)$

Fig. 4. Relationship between calcium (Ca) concentration in the petiole juice and blossom-end rot (BER) incidence including all fertilization methods (Expt. 2). **Significant at $P \leq 0.01$.

In contrast, high $\mathrm{NH}_{4}-\mathrm{N}$ concentration is often associated with increased incidence and severity of BER (Akl et al., 2003; DeKock et al., 1979, 1982; Pill and Lambeth, 1980; Pill et al., 1978). In general, the ratio of $\mathrm{NH}_{4}-\mathrm{N}$ to total $\mathrm{N}$ is higher in CRF than in commercial LF. The ratio was $33 \%$ to $35 \%$ in this experiment. It was reported that BER incidence increased drastically when the ratio was higher than $20 \%$ to 25\% (Akl et al., 2003; Hartman et al., 1986; Ikeda and Osawa, 1988). Therefore, the difference in the incidence of BER between treatments in the current study probably originated as a result of differences in Ca deficiency caused by the high $\mathrm{NH}_{4}-\mathrm{N}$ ratio in CRF.

Increase in the $\mathrm{NH}_{4}-\mathrm{N}$ concentration led to a decrease in the Ca concentration in the petiole juice under first truss during both seasons (Table 4). Thus, Ca uptake was probably suppressed by high $\mathrm{NH}_{4}-\mathrm{N}$ uptake in those trusses. Conversely, there was no significant difference in $\mathrm{NH}_{4}-\mathrm{N}$ concentration in the petiole juice and no relationship with $\mathrm{Ca}$ concentration at the other trusses. From these results, it may be difficult to conclude that BER incidence and $\mathrm{Ca}$ deficiency were caused by high $\mathrm{NH}_{4}-\mathrm{N}$ uptake. However, it is considered that high $\mathrm{NH}_{4}-\mathrm{N}$ content and the difference in the degree of nitrification to $\mathrm{NO}_{3}-\mathrm{N}$ in $\mathrm{CRF}$ are related to $\mathrm{Ca}$ uptake by plants and BER incidence, because the ratio of $\mathrm{NH}_{4}-\mathrm{N}$ concentration in the tank and BER incidence reduced with nitrifying treatment.

Table 5. Concentration of each nitrogen form in the xylem exudates in the different fertilization methods (Expt. 3).

\begin{tabular}{lccc}
\hline Treatment & \\
\hline MF & $\mathrm{NO}_{3}-\mathrm{N}\left(\mathrm{mg} \cdot \mathrm{L}^{-1}\right)$ & $\mathrm{NH}_{4}-\mathrm{N}\left(\mathrm{mg} \cdot \mathrm{L}^{-1}\right)$ & Organic $\mathrm{N}\left(\mathrm{mg} \cdot \mathrm{L}^{-1}\right)$ \\
PF & $182.9 \mathrm{a}^{\mathrm{x}}(38.0)^{\mathrm{y}}$ & $35.4(7.3)$ & $262.9 \mathrm{~b}(54.6)$ \\
TF & $125.1 \mathrm{~b}(24.4)$ & $38.2(7.4)$ & $349.7 \mathrm{a}(68.2)$ \\
ANOVA & $127.0 \mathrm{~b}(24.5)$ & $39.0(7.5)$ & $352.9 \mathrm{a}(68.0)$ \\
\hline
\end{tabular}

Xylem exudates were collected on 8 Dec. 2010.

${ }^{\mathrm{z}} \mathrm{MF}=$ mixed-fertilization; $\mathrm{PF}=$ packed bag-fertilization; $\mathrm{TF}=$ tank-fertilization

${ }^{\mathrm{y}}$ The rate to whole $\mathrm{N}$ concentration (\%).

${ }^{x}$ Different letters indicate significant differences among treatments $(P<0.05)$.

NS, *Nonsignificant or significant at $P \leq 0.05$, respectively.

$\mathrm{N}=$ nitrogen; ANOVA $=$ analysis of variance.

In contrast, there was little difference in the apparent nutrient uptake between CRFapplied treatments. BER incidence was remarkable on only the lower trusses with very little incidence on the upper trusses. Therefore, $\mathrm{Ca}$ uptake probably only differed between the treatments during the first half of the growing season.

Expt. 3: Uptake ratio of $\mathrm{NH}_{4}-\mathrm{N} \mathrm{NO}_{3}-\mathrm{N}$ and nitrogen conversion of the supplied fertilizer. The concentration of each $\mathrm{N}$ form in the xylem exudates is shown in Table 5. $\mathrm{NO}_{3}-\mathrm{N}$ concentration was lower in $\mathrm{PF}$ and $\mathrm{TF}$ than in $\mathrm{MF}$, whereas $\mathrm{NH}_{4}-\mathrm{N}$ concentration was almost the same between the treatments. Organic N concentration was the highest of the three $\mathrm{N}$ forms in each treatment and higher in PF and TF than in MF. In general, with increase in the $\mathrm{NH}_{4}-\mathrm{N}$ ratio in the fertilizer, decrease in the $\mathrm{NO}_{3}-\mathrm{N}$ concentration and increase in the concentration of amino acids in the xylem exudates were observed (Bialczyk et al., 2004; Lorenz, 1976; Lu et al., 2009). This is because the rate of $\mathrm{NO}_{3}-\mathrm{N}$ reduction at the roots is very low, and $\mathrm{NO}_{3}-\mathrm{N}$ is mainly reduced to $\mathrm{NH}_{4}-\mathrm{N}$ and amino acids in the leaves; the rate of $\mathrm{NH}_{4}-\mathrm{N}$ reduction at the roots is comparably high (Lorenz, 1976). From these results, the ratio of $\mathrm{NH}_{4}-\mathrm{N}$ uptake to $\mathrm{NO}_{3}-\mathrm{N}$ uptake was probably higher in $\mathrm{PF}$ and TF than in MF.

${ }^{15} \mathrm{~N}$ concentration in each $\mathrm{N}$ form in the xylem exudates is shown in Table 6. Conversion from $\mathrm{NH}_{4}-\mathrm{N}$ to the anion or cation form can be calculated by deducting ${ }^{15} \mathrm{~N}$ concentration in each form from that in whole $\mathrm{N}$. In each treatment, the conversion rate from $\mathrm{NH}_{4}-\mathrm{N}$ to the cation form was higher than that from $\mathrm{NH}_{4}-\mathrm{N}$ to the anion form because the ${ }^{15} \mathrm{~N}$ concentration in the anion 
Table $6 .{ }^{15} \mathrm{~N}$ concentration in each nitrogen form in the xylem exudates in the different fertilization methods (Expt. 3).

\begin{tabular}{|c|c|c|c|c|c|}
\hline \multirow[b]{2}{*}{ Treatment $^{\mathrm{z}}$} & \multirow{2}{*}{$\frac{\text { Whole } \mathrm{N}}{\begin{array}{c}{ }^{15} \mathrm{~N} \text { concn } \\
(\text { atom } \%)\end{array}}$} & \multicolumn{2}{|c|}{ Anion form } & \multicolumn{2}{|c|}{ Cation form } \\
\hline & & $\begin{array}{l}{ }^{15} \mathrm{~N} \text { concn } \\
(\text { atom } \%)\end{array}$ & $\begin{array}{c}\text { Difference from } \\
\text { whole N (atom \%) }\end{array}$ & $\begin{array}{l}{ }^{15} \mathrm{~N} \text { concn } \\
(\text { atom } \% \text { ) }\end{array}$ & $\begin{array}{c}\text { Difference from } \\
\text { whole N (atom \%) }\end{array}$ \\
\hline$\overline{\mathrm{MF}}$ & $3.4 \mathrm{~b}^{\mathrm{y}}$ & $3.0 \mathrm{~b}$ & -0.46 & 4.9 & $1.48 \mathrm{a}$ \\
\hline PF & $3.9 \mathrm{a}$ & $3.5 \mathrm{a}$ & -0.37 & 4.8 & $0.90 \mathrm{~b}$ \\
\hline $\mathrm{TF}$ & $4.2 \mathrm{a}$ & $3.9 \mathrm{a}$ & -0.28 & 5.1 & $0.94 \mathrm{~b}$ \\
\hline ANOVA & $*$ & $*$ & NS & NS & $*$ \\
\hline
\end{tabular}

${ }^{\mathrm{z}} \mathrm{MF}=$ mixed-fertilization; $\mathrm{PF}=$ packed bag-fertilization; $\mathrm{TF}=$ tank-fertilization.

${ }^{y}$ Different letters indicate significant differences among treatments $(P<0.05)$.

Ns, *Nonsignificant or significant at $P<0.05$, respectively.

$\mathrm{N}=$ nitrogen; ANOVA $=$ analysis of variance.

form was lower, whereas ${ }^{15} \mathrm{~N}$ concentration in the cation form was higher than that in whole $\mathrm{N}$. Therefore, $\mathrm{NH}_{4}-\mathrm{N}$ in the fertilizer would mostly be converted to organic $\mathrm{N}$ such as amino acids, because $\mathrm{NH}_{4}-\mathrm{N}$ concentration in xylem exudates was very low in each treatment. This result matches the high concentration of organic $\mathrm{N}$ in the xylem exudates.

From these results, the following mechanisms are suggested as possible causes of the difference in BER incidence between the treatments of Expt. 2: 1) in MF, it is difficult to induce $\mathrm{Ca}$ deficiency and increase BER incidence because the nitrification rate of the fertilizer is high and the rate of $\mathrm{NH}_{4}-\mathrm{N}$ uptake is comparatively low; and 2) in PF and TF, it is easier to induce $\mathrm{Ca}$ deficiency and increase BER incidence because the nitrification rate of the fertilizer is low and the rate of $\mathrm{NH}_{4}-\mathrm{N}$ uptake is comparatively high.

\section{Conclusion}

Efficient nitrification of the fertilizer from $\mathrm{NH}_{4}-\mathrm{N}$ to $\mathrm{NO}_{3}-\mathrm{N}$ is possible by combining the addition of bark compost (for the nest of nitrifying bacteria) and aeration of the water (to improve oxygen supply). Fruit yield was lower in TF and PF than in MF, but promoting nitrification in the water reserve tank in TF increased fruit yield to the same level as that observed in MF. Besides, the substrates treated by TF may have high reusability. The uptake ratio of $\mathrm{NH}_{4}-\mathrm{N} / \mathrm{NO}_{3}-\mathrm{N}$ was estimated to be lower in MF than in PF and TF. Therefore, compared with $\mathrm{PF}$ and $\mathrm{TF}$, it would be difficult to induce $\mathrm{Ca}$ deficiency and increase BER incidence in MF. Thus, the technique of "tank fertilization" of CRF in the root-proof capillary-wick irrigation system of tomato is possible by promoting nitrification in the water reserve tank.

\section{Literature Cited}

Akl, I.A., D. Savvas, N. Papadantonakis, N. LydakisSimantris, and P. Kefalas. 2003. Influence of ammonium to total nitrogen supply ratio on growth yield and fruit quality of tomato grown in a closed hydroponic system. Europ. J. Hort. Sci. 6:204-211.

Bialczyk, J., Z. Lechowski, and D. Dziga. 2004. Composition of the xylem sap of tomato seedlings cultivated on media with $\mathrm{HCO}_{3}$ and nitrogen source as $\mathrm{NO}_{3}{ }^{-}$or $\mathrm{NH}_{4}^{+}$. Plant Soil 263:265-272.

Bradfield, E.G. and C.G. Guttridge. 1984. Effect of night-time humidity and nutrient solution concentration on the calcium content of tomato fruit. Sci. Hort. 22:207-217.

Chiu, T. and C. Bould. 1976. Effects of shortage of calcium and other cations on ${ }^{45} \mathrm{Ca}$ mobility, growth and nutritional disorders of tomato plants (Lycopersicon esculentum). J. Sci. Food Agr. 27:969-977.

DeKock, P.C., A. Hall, R. Boggie, and R.H.E. Inkson. 1982. The effect of water stress and form of nitrogen on the incidence of blossomend rot in tomatoes. J. Sci. Food Agr. 33:509515 .

DeKock, P.C., A. Hall, R.H.E. Inkson, and R.A. Robertson. 1979. Blossom-end rot in tomatoes. J. Sci. Food Agr. 30:508-514.

Ehret, D.L. and L.C. Ho. 1986. Translocation of calcium in relation to tomato fruit growth. Ann. Bot. (Lond.) 58:679-688.

El-Gizawy, A.M. and P. Adams. 1986. Effect of temporary calcium stress on the calcium status of tomato fruit and leaves. Acta Hort. 178:37-41.

Gerard, C.J. and B.W. Hipp. 1968. Blossom-end rot of 'Chico' 'Chico Grande' tomatoes. Amer. Soc. Hort. Sci. 93:521-531.

Goodwin, P.B., M. Murphy, P. Melville, and W. Yiasoumi. 2003. Efficiency of water and nutrient use in containerized plants irrigated by overhead, drip or capillary irrigation. Aust. J. Exp. Agr. 43:189-194.

Hartman, P.L., H.A. Mills, and J.B. Jones, Jr. 1986. The influence of nitrate:ammonium ratios on growth, fruit development, and element concentration in 'Floradel' tomato plants. J. Amer. Soc. Hort. Sci. 111:487-490.

He, Y., S. Terabayashi, and T. Namiki. 1998. The effect of leaf position and time of sampling on nutrient concentration in the petiole sap from plants cultured hydroponically. J. Jpn. Soc. Hort. Sci. 67:331-336.

Ho, L.C. 1989. Environmental effects on the diurnal accumulation of ${ }^{45} \mathrm{Ca}$ by young fruit and leaves tomato plants. Ann. Bot. (Lond.) 63:281-288.

Ikeda, H. and T. Osawa. 1988. The effects of $\mathrm{NO}_{3} /$ $\mathrm{NH}_{4}$ ratios and temperature of the nutrient solution on growth, yield and blossom-end rot incidence in tomato. J. Jpn. Soc. Hort. Sci. 57:62-69 [in Japanese with English summary].

Imano, H., M. Masuda, and K. Murakami. 2011. Tomato cultivation by placing controlledrelease fertilizers on the wick in the root-proof capillary watering system. Hort. Res. (Jpn) 10:41-47 [in Japanese with English summary].

Incrocci, L., F. Malorgio, A. Della Bartola, and A. Pardossi. 2006. The influence of drip irrigation or subirrigation on tomato grown in closedloop substrate culture with saline water. Sci. Hort. 107:365-372.

Kinoshita, T. and M. Masuda. 2011a. Differential nutrient uptake and its transport in tomato plants on different fertilizer regimens. HortScience 46:1170-1175.
Kinoshita, T. and M. Masuda. 2011b. Effects of various substrates on growth and fruit yield in tomato forcing culture using a root-proof capillary wick. Hort. Res. (Jpn) 10:197-202 [in Japanese with English summary].

Lorenz, H. 1976. Nitrate, ammonium and amino acids in the bleeding sap of tomato plants in relation to form and concentration of nitrogen in the medium. Plant Soil 45:169-175.

Lu, Y.L., C.C. Xu, Q.R. Shen, and C.X. Huang. 2009. Effects of different nitrogen forms on the growth and cytokinin content in xylem sap of tomato (Lycopersicon esculentum Mill.) seedlings. Plant Soil 315:67-77.

Masuda, M. 2008. Innovative cultivation method using capillary wick covered with water permeable root-barrier material. Agr. Hort. 83:20-25 [in Japanese].

Masuda, M. and S. Fukumoto. 2008. Potential for tomato cultivation using capillary wick-watering method. Sci. Rpt. Faculty Agr. Okayama Univ. 97:49-54 [in Japanese with English summary].

Morikuni, H. and N. Shimada. 2000. The influence of nitrogen sources on blossom end rot of tomatoes grown in isolated bed culture. Jpn. J. Soil. Soc. Plant Nutr. 72:489-498 [in Japanese with English summary].

Morishige, A., M. Masuda, and K. Murakami. 2009. Fruit vegetable cultivation for balance in demand and supply of nutrient and water using capillary wick covered with water permeable root-barrier material. VIII. Growth and fruit yield of large-fruited tomato subjected to different strengths of nutrient solution for longterm forcing culture. Hort. Res. (Japan) 8(suppl 1):360 (abstr.) [in Japanese].

Pill, W.G. and V.N. Lambeth. 1980. Effects of soil water regime and nitrogen form on blossomend rot, yield, water relations, and elemental composition of tomato. J. Amer. Soc. Hort. Sci. 105:730-734.

Pill, W.G., V.N. Lambeth, and T.M. Hinckley. 1978. Effects of nitrogen form and level on ion concentrations, water stress, and blossom-end rot incidence in tomato. J. Amer. Soc. Hort. Sci. 103:265-268.

Santamaria, P., G. Campanile, A. Parente, and A. Elia. 2003. Subirrigation vs drip-irrigation: Effects on yield and quality of soilless grown cherry tomato. J. Hort. Sci. Biotechnol. 78:290-296.

Shinohara, M. 2006. Hydroponics with organic fertilizers-A method for building an ecological system of microorganisms in culture liquid by parallel mineralization method. Agr. Hort. 81:753-764 [in Japanese].

Shinohara, M., C. Aoyama, K. Fujiwara, A. Watanabe, H. Ohmori, Y. Uehara, and M. Takano. 2011. Microbial mineralization of organic nitrogen into nitrate to allow the use of organic fertilizer in hydroponics. Soil Sci. Plant Nutr. 57:190203.

Tanaka, T. 2003. Nutritional diagnosis indicator in drip-fertigation on tomato plants in greenhouse culture. Res. Bull. Aichi Agr. Res. Ctr. 35:7378 [in Japanese with English summary].

Truog, E. 1930. The determination of the readily available phosphorus soils. J. Amer. Soc. Agron. 22:874.

Westerhout, J. 1962. Relation of fruit development to the incidence of blossom-end rot of tomatoes. Neth. J. Agr. Sci. 10:223-234.

Wui, M. and T. Takano. 1995. Effect of temperature and concentration of nutrient solution during the stage of the fruit development on the incidence of blossom-end rot in fruit of tomato, Lycopersicon esculentum L. Environ. Control in Biol. 33:7-14 [in Japanese with English summary]. 